\title{
Economic factors affecting Thailand's frozen shrimp export volume to the United States and Japan
}

http://doi.org/10.21272/fmir.4(4).66-74.2020

He Shuquan, ORCID: https://orcid.org/0000-0002-4159-4365

$\mathrm{PhD}$, Professor, Department of Economics, Shanghai University, China

Matukorn Bu-iad

School of Economics Shanghai University, China

\begin{abstract}
A Study of Economic Factors Affecting Thailand's Frozen Shrimp Export Volume to the United States and Japan which hypothesized that there are economic factors that affect the quantity of frozen shrimp exports from Thailand to the United States, namely the Manufacturing Production Index classified by production activity, Frozen Seafood (MPI), Domestic Wholesale Shrimp Price $\left(P R I_{\text {shrimp }}\right)$, United States Gross Domestic Product $\left(\mathrm{GDP}_{\text {U.S.A. }}\right)$, Per Capita Income of US Population (PCI $\left.\mathrm{PIS.A.}_{\text {. }}\right)$, Rate Of Change In Private Consumption And Consumption Expenditures Of The US Private Sector ( $\mathrm{PCE}_{\text {U.S.A. }}$ ) and assumed that there are economic factors affecting the quantity of frozen shrimp exports to Japan, namely the Manufacturing Production Index classified by production activity, Frozen Seafood Category (MPI), Domestic Wholesale Shrimp Price $\left(P R I_{\text {shrimp }}\right)$, Japan Gross Domestic Product $\left(G D P_{\text {Japan }}\right)$, Per Capita Income Of Japanese Population $\left(P C I_{\text {Japan }}\right)$, Rate Of Change In Private Consumption And Consumption Expenditures Of The Japanese Private Sector ( $\mathrm{PCE}_{\mathrm{Japan}}$ ) which are consistent with the research of Pathumnakul, S., Khamjan, S., \& Piewthongngam, K. (2007). Will use secondary data by collecting data on a monthly basis from January 2017 to December 2019 with the analysis of complex regression equations. By the least squares estimation method, the study found that the economic factors affecting frozen shrimp export volume of Thailand to the United States in the same direction is manufacturing production index classified by production activity, frozen seafood category, wholesale shrimp prices in the country, the gross domestic product of USA, income per capita of the United States population and rate of change in US private consumption expenditure has no effect on the export volume of frozen shrimp from Thailand to the United States. For economic factors affecting the frozen shrimp export volume of Thailand to Japan in the same direction is statistically significant, the manufacturing production index classified by production activity, frozen seafood category, wholesale shrimp prices in the country, the gross domestic product of Japan, income per capita of the Japanese population and the rate of change in Japanese private consumption expenditure has no effect on the export volume of frozen shrimp from Thailand to Japan.
\end{abstract}

Keywords: economic factors, frozen shrimp, export volume.

JEL Classification: F12, F14.

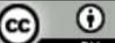

Cite as: Shuquan, H., Bu-iad, M. (2020). Economic factors affecting Thailand's frozen shrimp export volume to the United States and Japan. Financial Markets, Institutions and Risks, 4(4), 66-74. http://doi.org/10.21272/fmir.4(4).66-74.2020.

\section{Introduction}

Considering the export of processed shrimp over a 3-year period, the expansion of processed shrimp exports is increasing every year, which was consistent with the research of Thai processed shrimp export markets, Information and Communication Technology Center (2017) which in 2017 has an export value of just 1.28 hundred billion baht. 2 years ago in 2019, Thailand had exports totaling 1.38 hundred billion baht, the major processed shrimp export market of Thailand found that the United States imported processed shrimp as number 1 with an average import value of 6.2 ten billion baht for the second largest import of processed shrimp from Thailand is Japan, with an average import value of 2.3 ten billion baht (Table 1). 
Table 1. Important processed shrimp export markets of Thailand in 2017-2019

\begin{tabular}{|l|c|c|c|c|c|c|}
\hline Countries & \multicolumn{3}{|c|}{ Value: Million Baht } & \multicolumn{2}{c|}{ I } & \multicolumn{2}{c|}{ Proportion: Percent } \\
\hline & 2017 & 2018 & 2019 & 2017 & 2018 & 2019 \\
\hline USA & $62,508.20$ & $62,778.16$ & $62,247.33$ & 48.62 & 48.67 & 48.81 \\
\hline Japan & $22,306.99$ & $21,589.05$ & $27,651.94$ & 17.35 & 16.74 & 19.9 \\
\hline Canada & $8,169.88$ & $7,561.79$ & $7,659.86$ & 6.35 & 5.86 & 5.51 \\
\hline South Korea & $7,147.40$ & $5,664.08$ & $4,855.47$ & 5.56 & 4.39 & 3.5 \\
\hline UK & $2,966.15$ & $3,831.27$ & $4,634.65$ & 2.31 & 2.97 & 3.34 \\
\hline Spain & 678.71 & $3,136.16$ & $3,732.16$ & 0.53 & 2.43 & 2.69 \\
\hline Belgium & $1,848.06$ & $2,320.23$ & $3,324.54$ & 1.44 & 1.8 & 2.39 \\
\hline Germany & 2.558 .42 & $2,565.18$ & $2,945.95$ & 1.99 & 1.99 & 2.12 \\
\hline Australia & $3,767.51$ & $2,237.11$ & $2,683.92$ & 2.93 & 1.73 & 1.93 \\
\hline Taiwan & $1,540.77$ & $2,430.12$ & $2,541.08$ & 1.2 & 1.88 & 1.83 \\
\hline $\begin{array}{l}10 \text { countries in } \\
\text { total }\end{array}$ & $113,492.09$ & $114,113.15$ & $122,276.90$ & 88.27 & 88.46 & 88.02 \\
\hline Others & $15,082.80$ & $14,880.50$ & $16,646.30$ & 11.73 & 11.54 & 11.98 \\
\hline Total Value & $128,547.89$ & $128,993.65$ & $138,923.20$ & 100.00 & 100.00 & 100.00 \\
\hline
\end{tabular}

Source: UN COMTRADE.

From that information, which was consistent with the data of Bank of Thailand (2017) this represents the important export markets of frozen processed shrimp in Thailand, which are the United States and Japan. Which includes the order value of both countries? Each year, it is worth more than half of the value of Thai frozen shrimp exports. In the past, the expansion of the processed shrimp industry in Thailand has continued. It is the result of a wide variety of raw material advantages and enough for the market demand both in the country and abroad. Including having low labor costs, readiness to modify the production process to be competitive. Especially the production to meet the standards required by trade partners together with the government's food industry promotion policy from farm-level development to processing plants and marketing. As a result, the processed shrimp industry in Thailand has expanded. However, problems, obstacles and trade restrictions are increasing every time. For that reason, the researcher is interested to study the economic factors affecting the quantity of frozen shrimp exports of Thailand to the United States and Japan.

\section{Word Definitions}

"Thai frozen shrimp export volume to the United States and Japan" refers to the quantity of frozen shrimp exported as the primary unit exported to the United States and Japan.

"Manufacturing Production Index classified by production activity, Frozen seafood category" refers to an index that reflects industrial production classified by production activity, Frozen seafood category.

"Average domestic wholesale shrimp prices" refers to the average wholesale shrimp prices in the country from the prices of all 6 shrimp sizes at the shrimp market in Samut Sakhon Province, buying the prices of 6 shrimp sizes, namely $40 \mathrm{pcs}, 50 \mathrm{pcs}, 60 \mathrm{pcs}, 70 \mathrm{pcs}, 80 \mathrm{pcs}, 90 \mathrm{pcs}$ per kg.

"GDP of the United States and Japan" refers to household consumption indicates a household's affordability, with high PCE numbers indicating the growing economic climate of the United States and Japan.

"Per capita income of the population of the United States and Japan" refers to the income generated by the value of goods and services at market prices divided by the total population of the United States and Japan.

"Rate of change in private consumption expenditures of the United States and Japan" refers to household consumption expenditure indicates household expenditure, with high PCE numbers indicating growing economic conditions for the United States and Japan.

\section{Objectives}

To study the economic factors affecting the frozen shrimp export volume of Thailand to the United States and Japan. To illustrate the economic factors which are the relationships among the independent variables which are: Manufacturing production index classified by production activity, frozen seafood, Average wholesale shrimp prices in Thailand, Average Japanese Gross Domestic Product and the United States Gross Domestic Product, Per capita income of Japanese Population and Per capita income of the United States Population, Exchange rate of Japanese Private Consumption Expenditure and Exchange rate of the United States Private Consumption Expenditure whether they have statistically correlation, opposite correlation or can not be 
explained the relationship with the dependent variable which is: the quantity of frozen shrimp exports of Thailand to the United States and Japan.

\section{Hypotheses}

Hypotheses 1: Manufacturing production index classified by production activity, frozen seafood (MPI) has a statistically significant correlation with the quantity of frozen shrimp exports of Thailand to the United States and Japan.

Hypotheses 2: Average wholesale shrimp prices in Thailand $\left(P R I_{\text {Shrimp }}\right)$ has a statistically significant opposite correlation with the quantity of frozen shrimp exports of Thailand to the United States and Japan.

Hypotheses 3: Average Japanese Gross Domestic Product $\left(G D P_{\text {Japan }}\right)$ and the United States Gross Domestic Product $\left(\mathrm{GDP}_{\text {U.S.A. }}\right)$ have a statistically significant correlation with the quantity of frozen shrimp exports of Thailand to the United States and Japan.

Hypotheses 4: Per capita income of Japanese Population $\left(P C I_{\text {Japan }}\right)$ and Per capita income of the United States Population (PCI $\mathrm{P}_{\text {U.S.A. }}$ ) have a statistically significant correlation with the quantity of frozen shrimp exports of Thailand to the United States and Japan.

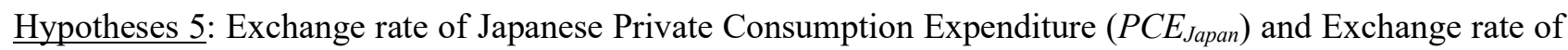
the United States Private Consumption Expenditure (PCE U.S.A. $_{\text {. }}$ ) have a statistically significant correlation with the quantity of frozen shrimp exports of Thailand to the United States and Japan.

\section{Literature Review}

Shrimp farming in Thailand started in year 1935 and developed into a very important industry in Thailand and achieved its title as the number one shrimp producer in 1991 (Sriboonchitta, 2001). In its introduction stage, shrimp farming began in the east coast of the Gulf of Thailand for domestic market, then expanded to export market after the continuing growth in global demand from North America, Japan and Europe provided a strong commercial rationale for turning shrimp aquaculture into a major industry (Lebel, 2002).

In general export and import competitiveness are assessed from price and quality from the importer's point of view. Price of a product is determined based on activities including production (cost of farm raw material production inputs and factory- level processing costs), shipping costs, marketing costs, and costs for sales and after-sales service (Porter, 2008).

Price competitiveness between countries is also influenced by factors like wage rates and input costs within those countries (Hallak \& Schott, 2011).

A number of studies have shown that price is an element of competitiveness in agricultural industries, including seafood and shrimp production (Islam \& Habib, 2013; Jung et al., 2011; Rieple \& Singh, 2010; Sangho et al., 2011; Zokaei \& Simons, 2006). While quality can be defined as the perceived fitness of the received good for the purpose the consumer intends to use it for (Hallak \& Schott, 2011). At the country level, quality may be generalized into a country of origin (COO), which is a stereotypical set of assumptions about the quality and characteristics of the country's goods in general (Porter, 2011).

Import export activity reflected in a country's trade balance. Trade liberalization policies that seek to eliminate trade barriers to increase exports, but on the other side can also increase imports. A country aims to have a surplus balance of trade or exports greater than imports. Thus, trade liberalization will affect the trade balance of exports and imports growth. Growth of exports and imports that determine the balance of trade surplus or deficit (Wati, L. A., Chang, Wen-I, \& Mustadjab, Moch Muslich, 2013)

\section{Concepts and Theories}

In the study of economic factors affecting the quantity of frozen shrimp exports of Thailand to the United States and Japan, the researchers conducted studies and research on concepts and theories, as well as relevant articles and studies. It is divided into 3 parts as follows:

\section{1.) Data of the processed shrimp industry in Thailand}

From the Economic Report entitled "Processed Shrimp: Products to Watch" Office of Industrial Economics (2019). Currently, Thai shrimp exporters have adapted a lot to the processed market. By improving product 
quality to create added value, including processing shrimp products in different ways, seasoning fresh shrimp into semi-finished products such as shrimp, bread, etc. Thailand is a big market in the distribution network by bringing fresh shrimp as ready-to- eat food. The main export market for processed shrimp is the US market, especially the shrimp cocktail, the second most important markets are Japan and Singapore. Nowadays, shrimp exporters have promoted the export of processed shrimp products in their main markets by: In cooperation with major US department stores, the largest buyer of Thai shrimp, Sams Club, Wall Mart network with the highest sales in the United States, and organizing director. Trader Jae's informed the Department of Export Promotion that they would buy no less than 20 types of ready-to-eat food products to promote sales to customers across the United States, a great opportunity to export processed shrimp or prawns. Currently, Vietnam is trying to become a processed shrimp producer like Thailand. But at this time, it still can't, India wants to. But stuck in labor and hygiene problems But Thai exporters have to be wary of these two competing countries as they will be formidable contenders for future Thai processed shrimp exports as both countries are ready for raw materials only. But it only needs the development of technology in production, skill of labor only, while Thailand has to rely on large shrimp imports from India and Myanmar because shrimp farmers in Thailand do not favor large shrimp in order to speed up the shrimp farming cycle. In 1 year for up to 3 cycles, therefore, shrimp are imported to replace the shrimp that cannot be produced domestically and to promote the continuous growth of the processed shrimp industry.

US Market. The US Department of Commerce announces the results of its review of the primary shrimp market tax review. Administrative review on March 9, 2007, Thailand was charged with the primary market response tax at the rate of 2.34-57.64 percent, while the national average rate between 5.79- 6.82 percent was reduced to 4.24 percent. There are only about 23 small and medium-sized companies that benefit only because nearly 60 of the large exporters are all accepting private-sector offerings in the US by paying the private sector.

Shrimp farming in the United States in exchange for maintaining the same counter-market tariff of 5.79-6.82 percent for another year to reduce the risk of increased market tariffs after an annual review. As a whole, Thailand still has an advantage over its main competitors in the US market, so Thai shrimp exports to the US market in the second half of the year are expected to increase.

Japanese market. Export of shrimp products to the Japanese market had a significant positive factor after cooperated JTEPA agreement with Japan, which resulted in an immediate drop in the import tax on frozen shrimp and processed shrimp from 5.0 percent to 0 percent, which took effect In October 2007, Thai shrimp exports to the Japanese market in the second half of 2007 are likely to continue to expand from the first half of 2007, Thailand has benefited from Japan detecting banned substances. In shrimp products from major competitors such as Indonesia, Vietnam and China, causing shrimp products importers from Japan to import shrimp products from Thailand more and more to meet the demand.

2) Supply Theory. Supply refers to the number of goods or services that the producer and the seller intends to produce for a certain period of time at different price levels of that kind of goods or services, the amount of goods that a producer intends to sell at a certain price level in each period is known as the selling quantity. This volume is the maximum that a manufacturer is willing to sell at a certain price level under the prevailing conditions, the sales quantity for a given period may not be equal to the amount that the manufacturer actually sold, the sales quantity will be greater than the actual sold quantity in case the consumer has less demand for purchases than the amount offered by the manufacturer, and as the case with the offered quantity, sales volume is a dynamic variable because it is the amount of goods or services measured over a period of time. Goods or services per unit (Law of supply) is the amount of goods or services that a manufacturer wants to offer for sale over a period of time, directly varies with the price level of that kind of goods or services. In short, sales volumes always change in the same way as prices. That is, if the product price increases, the sales volume increases, and if the product price decreases, the sales volume decreases as well. That is, when the price is higher, it will motivate more manufacturers to produce that kind of product, which was consistent with the research of Mei Cao (2012).

3) Theory of demand. The volume of product demand inversely with the price is due to two reasons

1. Income Effect. When product prices rise, but the fixed income of the consumer allows the consumer to purchase a smaller quantity of the product, which is the lower purchasing power. Despite having the same amount of income but the price of the product is lower, so the consumers can buy the product in larger quantities, that is, the actual income of the consumer increases, which was consistent with the research of Mishra, Dr. R. (2008). 
When the price of a particular product goes up while the price of another product which can replace it remains constant, the consumer feels that this particular product is more expensive, so they buy less quantity of this product. On the other hand, when the price of a particular product goes down, consumers buy another product with a fixed price that can replace it in smaller quantities. Therefore, from the theory of the law of demand, the factors affecting the demand for goods are the price of the product and the price of the substitute product. There are also other factors that affect the demand for the product such as the population income, the demand for goods changes, possibly more or less depending on the nature of the goods - normally as the population increases, the demand for goods and services increase in each season or festival, consumption will vary depending on the nature of the product and the use of that particular product.

\section{Methodologies and Study Results}

This study was based on data from secondary sources, which were quantified by quantitative data. The population used for this study was the quantity of Thai frozen shrimp export volume to the United States, economic factors are industrial production index classified by production activity, frozen seafood category, domestic wholesale shrimp prices, US gross product, per capita income of US population, rate of change in private consumption and consumption expenditures of the US private sector. Thai frozen shrimp export volume to Japan, economic factors are industrial production index classified by production activity, frozen seafood category, domestic wholesale shrimp prices, Japan gross product, per capita income of Japanese population, rate of change in private consumption and consumption expenditures of the Japanese private sector, by a sample of monthly data from January 2017 to December 2019.

\section{Study Tools}

To study the economic factors affecting the frozen shrimp export volume of Thailand to the United States and Japan by Multiple Linear Regressions with method of OLS (Kurata H., 2009)

\section{The variables used in the study are as follows:}

The dependent variable: The quantity of frozen shrimp exports from Thailand to the United States (EXP U.S.A.)

The independent variables : Manufacturing production index classified by production activity, frozen seafood category (MPI), average wholesale shrimp prices in Thailand $\left(P R I_{\text {shrimp }}\right)$, US gross domestic product ( $\left.G D P_{\text {U.S.A. }}\right)$, per capita income of United States Population $\left(P C I_{\text {U.S.A. }}\right)$, rate of change in private consumption and consumption expenditures of the US private sector $\left(P C E_{\text {U.S.A. }}\right)$

\section{From the calculation results, the equation is as follows:}

$$
\begin{aligned}
E X P_{\text {U.S. } .}=-9060.294+57.77567 M P I-31.92218 P R I_{\text {Shrimp }}+430.6160 G D P_{\text {U.S.A. }} & (1.075454) \\
& (6.407537)^{* *}(-1.282483) \\
+ & 0.414931 P C I_{\text {U.S.A. }}-168.222 P C E_{\text {U.S.A. }} \\
& (1.013381) \quad(-0.508911)
\end{aligned}
$$

Using the F-Stat test statistic to verify the reliability of the whole equation, the calculation results were obtained $\mathrm{F}=44.58662$ and the statistical significance $=0.0000$, which the calculated statistical significance was less than 0.01 . As a result, the main hypothesis is rejected Ho: no independent variables affect the quantity of frozen shrimp exports of Thailand to the United States. However, the secondary hypothesis H1: There is at least one dependent variable that significantly affect the quantity of frozen shrimp exports of Thailand to the United States at a confidence level of $99 \%$. After that t-Stat was used to test the relationship of dependent variable with independent variable, which independent variable was the quantity of frozen shrimp exports from Thailand to the United States and independent variables, namely factors from various data calculated. The variables in the equation can explain the economic factors that affect the quantity of frozen shrimp exports of Thailand to the United States by $86.1919 \%$ while the other $13.8081 \%$ comes from other factors with 1 significant variables, namely the manufacturing production index classified by production activity, frozen seafood (MPI) while the variables which had no significant effect on the quantity of frozen shrimp exports from Thailand to the United States had 4 variables: 1. Price Domestic Wholesale Shrimp $\left(P R I_{\text {Shrimp }}\right) 2$. United States Gross Domestic Product (GDP $\left.P_{\text {U.S.A. }}\right)$ 
3. United States Per Capita Income of Population $\left(P C I_{\text {U.S.A. }}\right)$ 4. Changing Rate Of Consumption And Consumption Expenditure Of US Private Section $\left(P C E_{\text {U.S.A. }}\right)$. The coefficient of the variables can be described as follows: The manufacturing production index classified by production activity, frozen seafood (MPI) has a coefficient of 57.77567. The industrial sector, classified by production activity, frozen product increased by 1 point, will increase the frozen shrimp export volume to the United States by 57.77567 tons, which is related in the same direction and according to the assumptions set.

The dependent variable was the quantity of frozen shrimp exports from Thailand to Japan $\left(E X P_{\text {Japan }}\right)$

The independent variables were manufacturing production index classified by production activity, frozen seafood (MPI), average wholesale shrimp prices in Thailand $\left(P R I_{\text {Shrimp }}\right)$, Average Japanese Gross Domestic Product $\left(G D P_{\text {Japan }}\right)$, Per capita Income of Japanese Population $\left(P C I_{\text {Japan }}\right)$, Exchange rate of Japanese Private Consumption Expenditure $\left(P C E_{J a p a n}\right)$

From the calculation results, the equation is as follows:

$$
\begin{gathered}
E X P_{\text {Japan }}=1842.209+22.12142 M P I-18.06317 P R I_{\text {Shrimp }}-168.7928 G D P_{\text {Japan }} \\
(5.187223)^{* *} \quad(-2.821450)^{* *} \\
-0.000262 P C I_{\text {Japan }}-3.129602 P C E_{\text {Japan }} \\
(-1.044142) \quad(-0.081485)
\end{gathered}
$$

Using the F-Stat test statistic to verify the reliability of the whole equation, the calculated result was $\mathrm{F}=$ 27.46498 and the statistical significance $=0.0000$, the calculated statistical significance was less than 0.01 . As a result, the main hypothesis was rejected Ho: no independent variables had any effect on the quantity of frozen shrimp exports of Thailand to Japan. But It will accept the secondary hypothesis H1: There is at least 1 dependent variable that has a significant effect on the quantity of frozen shrimp export of Thailand to Japan at a confidence level of $99 \%$. After that t-Stat was used in testing the relationship of dependent variable with independent variable one by one, where dependent variable was the quantity of frozen shrimp exports from Thailand to Japan and independent variable, namely factors from various data calculated, it can be concluded that The variables in the equation can explain the economic factors that affect the quantity of frozen shrimp exports of Thailand to Japan, $76.0136 \%$, while the other $23.9864 \%$ comes from other factors with 2 significant variables. The 2 main variables were the manufacturing production index classified by the production activity, frozen seafood (MPI) and the domestic wholesale shrimp price (PRI Shrimp)

The variables which did not affect the quantity of frozen shrimp exports from Thailand to Japan were as, there are 3 variables: 1 . Gross Domestic Product of Japan $\left(G D P_{\text {Japan }}\right), 2$. Income per capita of Japanese Population $\left(P C I_{\text {Japan }}\right)$, Japanese private consumption and consumption expenditures $\left(P C E_{\text {Japan }}\right)$.

The coefficient of the variables was as follows: The manufacturing production index classified by the production activity, frozen seafood $(M P I)$ had a coefficient of 22.12142. It can be explained that the manufacturing production index classified by the production activity, frozen shrimp had 1 point increased. Which impacted on the Increase of export volume of frozen shrimp to the United States by 22.12142 tons, which is in the same direction and in line with the assumptions.

Domestic wholesale shrimp price (PRI Shrimp) has a coefficient of -18.06317. It can be explained that the change in domestic wholesale shrimp price increases by 1 baht, which will reduce the frozen shrimp export volume to Japan by -18.06317 tons, which are in the opposite direction and do not follow the assumptions.

\section{Conclusions and Recommendations}

From the study of economic factors affecting the frozen shrimp export volume of Thailand to the United States and Japan, it was found that different factors yield the following results:

\section{Manufacturing Production Index classified by production activity, The frozen seafood (MPI)}

Has a statistically significant correlation with the quantity of frozen shrimp exports of Thailand to the United States and Japan, in line with the hypothesis and the theory of analyze fundamental factors indicating consumption behavior, which these conditions are reflected in the manufacturing production index classified by production activity, frozen seafood. The increasing proportion of the frozen seafood category will affect the amount of frozen shrimp exports of Thailand to the United States and Japan, in line with the theory of supply by causing the amount of frozen shrimp exports of Thailand to the United States and other countries. 


\section{Domestic wholesale shrimp prices (PRI $\underline{\text { SHRIMP }}$ )}

Has a statistically significant opposite correlation with the quantity of frozen shrimp exports of Thailand to Japan, which is based on the assumptions and rules of demand theory, that is the purchase demand is inversely proportional to the price of the product. From research of Menasveta, P. (1992) the results of the study of shrimp demand for Thai export to Japan found that wholesale prices in Thailand were the key factor determining export demand. Which correlated with Japan, where the need to import various types of frozen shrimp from Thailand However, the domestic wholesale shrimp price $\left(P R I_{\text {Shrimp }}\right)$ could not be significantly correlated with the quantity of frozen shrimp exports of Thailand to the United States, which the study results were consistent with the research of Thai Union Feed mill Company Limited (2017)The study concluded that the average price of imported frozen shrimp in Thailand was not statistically significant to the determination of the frozen shrimp import demand of the United States. It can be said that Thailand has a significant share of the market in the United States, along with the trade nature. Between exporters in Thailand and importers in the United States, there is a relatively stable contract to keep shrimp supply to meet demand despite changing prices.

\section{GDP of the United States and Japan}

Could not be significantly correlated with the quantity of frozen shrimp exports of Thailand to the United States and Japan, the results were consistent with Tabarestani, M., Keithly, W. R., \& Marzoughi-Ardakani, H. (2017)The study concluded that the GDP of Japan had a correlation in the opposite direction to the demand for frozen shrimp from Thailand which did not meet the hypothesis. Perhaps during that time, economic growth in both the United States and Japan was in a state of stagnation and recession. But when compared with the import of frozen shrimp from Thailand, although it has decreased somewhat but lesschange compared to the economic negative effects of the United States and Japan, which could explain how food is one of the four most important human factors despite the economic downturn. But it still needs to be consumed, it might be good as well, if in the sense that the economy is not good, people will save more by eating ready- made meals without wasting by eating out or cooking for themselves.

\section{Per capital income of the United States and Japan population $(P C I)$}

Could not be explained the relationship with the amount of frozen shrimp exports of Thailand to the United States and Japan.Consumers in the United States and Japan often enjoy the convenience of eating and reduced consumption of frozen shrimp from Thailand as income increased. The study concluded that the per capita income of the Japanese population did not significantly influence the quantity of Thai frozen shrimp exports to Japan.

\section{The rate of change in private consumption expenditures of the United States and Japan $(P C E)$}

Could not be explained in relation to the volume of Thai frozen shrimp exports to the United States and Japan, which can be described in the same way as the per capita income of the US and Japan population.

That is, despite the increase in consumption expenditures of the US and Japan population, which was consistent with the data of The International Monetary Fund (2019) does not mean that they will consume more of Thai frozen shrimp. The United States and Japan may consume high-priced seafood products such as salmon or lobster.In case of bad economy or low income, they may turn to the consumption of frozen shrimp from Thailand more because it is convenient in terms of consumption and inexpensive. Thus, causing the change in consumption expenditure, The United States and Japan had no significant influence on the quantity of frozen shrimp exports of Thailand to the United States and Japan.

\section{Recommendations for this study}

Entrepreneurs should expand shrimp exports to other markets in any other regions, especially markets in Asia which are not far away from Thailand. Moreover, countries in this region currently have more and more purchasing power. It can also support Thai branding shrimp exporters to maintain their market share in the global market.

\section{Recommendations for the further study}

As in the period of this study, we have experienced a recession in the financial crisis, which had an affect on some of frozen food export businesses as well as consumer confidence. Therefore, in the future study, the study 
period may be divided into 2 periods, pre-crisis and post-crisis studies, which will help the results of the study be more interesting and more reliable. There are also other factors which were not mentioned in this study that may have an impact on the quantity of frozen shrimp exports, for instance the exchange rate, average price of frozen shrimp from competing countries as well as the international political relations, etc. These factors mentioned above are highly recommended to apply in the future study.

Author Contributions: conceptualization, He Shuquan; methodology, He Shuquan; validation, $\mathrm{He}$ Shuquan; formal analysis He Shuquan; investigation He Shuquan, Matukorn Bu-iad; resources, He Shuquan, Matukorn Bu-iad; data curation Matukorn Bu-iad; writing - original draft preparation, Matukorn Bu-iad; writing - review and editing, He Shuquan; visualization, Matukorn Bu-iad; supervision, He Shuquan; project administration, He Shuquan.

\section{References}

1. Bank of Thailand. (2020). Production Industrial Index Classified by Production Activity Frozen seafood category. Retrieved from: http://www.bot.or.th/

2. Cao, M. (2012). Supply Chain Collaboration. Springer Science \& Business Media, 198. Retrieved from: https://www.springer.com/gp/book/9781447145905

3. Dwivedi, D. N. (2009). Principles of Economics, 2Nd Edition. Vikas Publishing House, 12. Retrieved from: https://www.vikaspublishing.com/books/business-economics/economics/principleseconomics/9788125916512/

4. Hallak, J. C., \& Schott, P. K. (2011). Estimating cross-country differences in product quality, The Quarterly Journal of Economics, 126, 417-474. Retrieved from: https://econpapers.repec.org/ RePEc:oup:qjecon:v:126:y:2011:i:1:p:417-474

5. Information and Communication Technology Center. Office of the Permanent Secretary, Ministry of Commerce in cooperation with the Customs Department. (2020). Thai processed shrimp export markets. Retrieved from: http://www.ops3.moc.go.th/

6. International Monetary Fund, Gross Domestic Product, Per Capita Income, and Transition Rate of Private Consumption Expenditure of the United States and Japan. (2019). Retrieved from: http://www.bloomberg.or.th/

7. Islam, S. B., \& Habib, M. M. (2013) Supply chain management in fishing industry: A case study, International Journal of Supply Chain Management, 2(2), 40-50. Retrieved from: https://ojs.excelingtech.co.uk/index.php/IJSCM/article/view/753

8. Jung, H. D., Choi, Y. S., Cheon, D. W., \& Kim, K. H. (2011). Value chain the economic impacts of native Korean cattle industry, Korean Journal of Agricultural Management and Policy, 38(4), 867-887. Retrieved from: https://www.koreascience.or.kr/article/JAKO201734964190436.page

9. Kurata, H. (Ed.). (2009). A New Measure for the Efficiency of the Ordinary Least Squares Estimator in a General Linear Regression Model Economic Society of Yamaguchi University, 10(21).

10. Lebel, L. et al. (2002). Industrial transformation and shrimp aquaculture in Thailand and Vietnam: Pathways to ecological, Social and economic sustainability, 31(4), 311-323. Retrieved from: https://pubmed.ncbi.nlm.nih.gov/12174602/

11. Menasveta, P. (1992). Shrimps Culture Industry in Thailand, 691-699. https://doi.org/10.1016/b978-0444-88606-4.50039-4

12. Ministry of Industry, Office of Industrial Economics. (2017). Information of the processed shrimp industry of Thailand 2017. Retrieved from: https://apps.fas.usda.gov/newgainapi/api/report/ downlo adrep ortbyfilename?filename $=$ Seafood\%20Report_Bangkok_Thailand_5-8-2018.pdf

13. Mishra, Dr. R. (2008). Industrial Economics and Management Principles. Firewall Media, 284. Retrieved from: https://books.google.com.cy/books/about/Industrial Economics and Management Prin.html?id= 7V2jidPpOAsC\&hl=en\&output $=$ html text 
14. Pathumnakul, S., Khamjan, S., \& Piewthongngam, K. (2007). Procurement decisions regarding shrimp supplies for Thai shrimp processors. Aquacultural Engineering, 37(3), 215221. https://doi.org/10.1016/j.aquaeng.2007.06.002

15. Porter, M. E. (2008). Competitive advantage: Creating and sustaining superior performance, New York: Simon and Schuster. Retrieved from: https://www.hbs.edu/faculty/Pages/item.aspx?num=193

16. Porter, M. E. (2011). The competitive advantage of nations, New York: Simon and Schuster. Retrieved from: https:/www.simonandschuster.com/books/Competitive-Advantage-of-Nations/Michael-EPorter/9781451651492

17. Rieple, A., \& Singh, R. (2010). A value chain analysis of the organic cotton industry: The case of UK retailers and Indian suppliers, Ecological Economics, 69(11), 2292-2302. Retrieved from: https://ideas.repec.org/a/eee/ecolec/v69y2010i11p2292-2302.html

18. Sangho, Y., Labaste, P., \& Ravry, C. (2011). Growing Mali's mango exports: Linking farmer to market through innovations in the value chain, in Yes, Africa can: Success stories from a dynamic continent, pp. 167-183, Washington, DC: World Bank Publications. Retrieved from: https:/www.semanticscholar.org /paper/Growing-Mali's-mango-exports-\%3A-linking-farmers-to-SanghoLabaste/f1a4e088fa09a995fbf3320d2e157ce115abda9a

19. Sriboonchitta, S. (2001). Thai shrimps in the world production and market, agribusiness research on marketing and trade, Chiang Mai: Multiple Cropping Center, Chiang Mai University. Retrieved from: https://edepot.wur.nl/36156

20. Tabarestani, M., Keithly, W. R., \& Marzoughi-Ardakani, H. (2017). An Analysis of the US Shrimp Market: A Mixed Demand Approach. Marine Resource Economics, 32(4), 411429. https://doi.org/10.1086/693360

21. Thai Union Feedmill (TFM) Thai Union Feedmill Company Limited Wholesale shrimp prices in Thailand January 2017 - December 2019. (2019). Retrieved from: www.thaiunionfeedmill.com

22. Wati, L. A., Chang, Wen-I, \& Mustadjab, Moch Muslich (Eds.). (2013). Competitiveness of Indonesian Shrimp Compare with Thailand Shrimp in Export Market. 16(1), 31. https://doi.org/10.21776/ub.wacana

23. Zokaei, A. K., \& Simons, D. W. (2006). Value chain analysis in consumer focus improvement: A case study of the UK red meat industry, International Journal of Logistics Management, 17(2), 141. Retrieved from: http://www.irbis-nbuv.gov.ua/cgi-bin/irbis_nbuv/cgiirbis_64.exe?C21COM=2\&I21DBN =UJRN \&P21DBN=UJRN\&IMAGE_FILE DOWNLOAD=1\&Image file name=PDF/imfi_2016_13 3(contin. 1) 6.pdf 